\title{
Optimising Cropping Techniques for Nutrient and Environmental Management in Organic Agriculture
}

\author{
Ulrich Köpke ${ }^{1,2}$, Miriam Athmann ${ }^{1,2}$, Eusun Han ${ }^{1,2} \&$ Timo Kautz ${ }^{1,2}$ \\ ${ }^{1}$ Institute of Organic Agriculture, University of Bonn, Germany \\ ${ }^{2}$ Campus Klein-Altendorf, University of Bonn, Germany \\ Correspondence: Ulrich Köpke, Institute of Organic Agriculture, University of Bonn, D-53115 Bonn, Germany. \\ Tel: 49-228-735-615. E-mail: ukiol@uni-bonn.de
}

Received: January 28, 2015 Accepted: February 17, $2015 \quad$ Online Published: June 20, 2015

doi:10.5539/sar.v4n3p15

URL: http://dx.doi.org/10.5539/sar.v4n3p15

\begin{abstract}
Depth and architecture of root systems play a prominent role in crop productivity under conditions of low water and nutrient availability. The subsoil contains high amounts of nutrients that may potentially serve for nutrient uptake by crops including finite resources such as phosphorus that have to be used in moderation to delay their exhaustion. Biopores are tubular shaped continuous soil pores formed by plant roots and earthworms. Taproot systems especially those of perennial legumes can make soil nutrients plant available from the solid phase and increase the density of vertical biopores in the subsoil thus making subsoil layers more accessible for succeeding crops. Density of larger sized biopores is further enhanced by increased abundance and activity of anecic earthworms resulting from soil rest and amount of provided feed. Nutrient rich drilospheres can provide a favorable environment for roots and nutrient uptake of subsequent crops. Future efficient nutrient management and crop rotation design in organic agriculture should entail these strategies of soil fertility building and biopore services in subsoil layers site specifically. Elements of these concepts are suggested to be used also in mainstream agriculture headlands, e.g. as 'Ecological Focus Areas', in order to improve soil structure as well as to establish a web of biodiversity while avoiding constraints for agricultural production.
\end{abstract}

Keywords: root system, biopore, drilosphere, endoscopy, subsoil

\section{Introduction}

In organic agriculture, high quality crop production and ecosystem health are strongly affected by soil quality. Soil quality can be distinguished at least as having two components. Firstly, the production functions that enable efficient sustainable net production of crops with optimised process and product qualities. Secondly, the ecological functions like filter and buffer functions, biodiversity, self-regulation and soil resilience.

In mainstream agriculture nutrient management has focused on directly increasing the nutrient concentration of the soil solution of the Ap horizon by fertilization with soluble nutrients. High rooting density meets a nutrient rich topsoil as a result of high fertilization.

Highly soluble mineral fertilisers are not permitted to be used in organic agriculture. In contrast to mainstream agriculture, organic agriculture typically has to deal with a scarcity of nutrients. Strategies making the nutrients in the system internally available, e.g. via biological nitrogen fixation or weathering, or keeping the nutrients potentially available in the long-term as a function of cycling, have to be used efficiently. Instead of directly increasing nutrient intensity and capacity of the soil via fertiliser inputs from outside, the farm nutrient management in organic agriculture relies on using and enhancing biological and microbiological processes primarily driven by agronomic measures like crop rotation design and tillage managing stationary nutrient flows. A larger part of the plant nutrients in the soil may derive from the solid phase that consists of mineral particles and different sources of soil organic matter. Consequently, nutrient management has to be considered as the optimised combination of resources that are restricted or have to be made plant available by achieving an optimised utilization, e.g. via increased rooting density and efficiency of nutrient absorption (Köpke, 1995).

For a long time research has neglected the capacity of nutrients bound in the subsoil, although for instance between 25 and 70\% of total soil P may be allocated in subsoil layers (Godlinski et al., 2004; Kautz et al., 2013a). Thus, in the case of $\mathrm{P}$ the subsoil may provide supply with a finite resource that has to be used in moderation to 
delay its exhaustion. Also, weathering in the subsoil and the release of potassium, magnesium and other nutrient elements from clay minerals have not been sufficiently investigated so far. Nevertheless, compared with the Ap horizon, only a relatively small proportion of the soil volume is considered as actively contributing to plant nutrient uptake in the bulk subsoil.

In natural ecosystems not directly affected by anthropogenic activities, nutrient uptake of the vegetation is almost completely performed by the solid phase. Thus, mimicking nature, as requested by Sir Albert Howard, a pioneer of organic agriculture (Howard, 1943) should entail the mobilisation of nutrients from the solid phase in the subsoil. In general, the spatial accessibility of less mobile nutrients like $\mathrm{P}$ and $\mathrm{K}$ is lower in the untilled subsoil compared with the tilled topsoil. Hence, any strategy of nutrient acquisition from the subsoil has to consider the size and architecture of the root systems and the extension of the rhizosphere as well as various biochemical strategies of the crop as essential measures. Subsoil accessibility by crop roots is enabled by channeling the bulk soil with larger sized biopores formed by taproot systems and earthworms. Recently in a comprehensive review, Kautz (2014) reported the current state of knowledge on the functions of biopores in agricultural soils and outlines consequences for organic management. Less is known about biopores' services that may provide additional environmental off-site benefits, i.e. biodiversity that may result in higher resilience of the agroecosystem. By identifying and managing the functions of biopores, they may provide ecological and environmental services for vital and sustainable agroecosystems.

This paper deals with an overview on our recent research on developing cropping systems that enable better use of water and nutrients from the subsoil. The overall aim is to create and manage large sized biopores in order to enable better access to deeper soil layers, to enhance water and nutrient uptake via biopores formed by roots and earthworms and to deliver also above ground ecological services. We end our journey with a conclusions and outlook section.

\section{Accessing the Subsoil}

\subsection{Creating Biopores}

Biopores are round-shaped channels formed by roots after their decay as well as those designed by earthworms which often use and widen biopores that were preformed by roots. Allorhizal root systems of dicots (taproots) leave larger sized biopores than fibrous more homogeneously distributed root systems of monocots. Our research on biopores is grounded in the early observations of Albert Schulz-Lupitz who developed his commercial farm on very poor sandy soils in the midst of the $19^{\text {th }}$ century. He reported higher tuber yields after cultivating lupin as a preceding green manure crop to potatoes. This effect was not based on residual nitrogen of the legume only but on biopores created by lupin taproots that could penetrate and cross dry and iron-cemented subsoil layers and which enabled access of potato roots to water holding subsoil layers beneath (Schultz-Lupitz, 1895). 


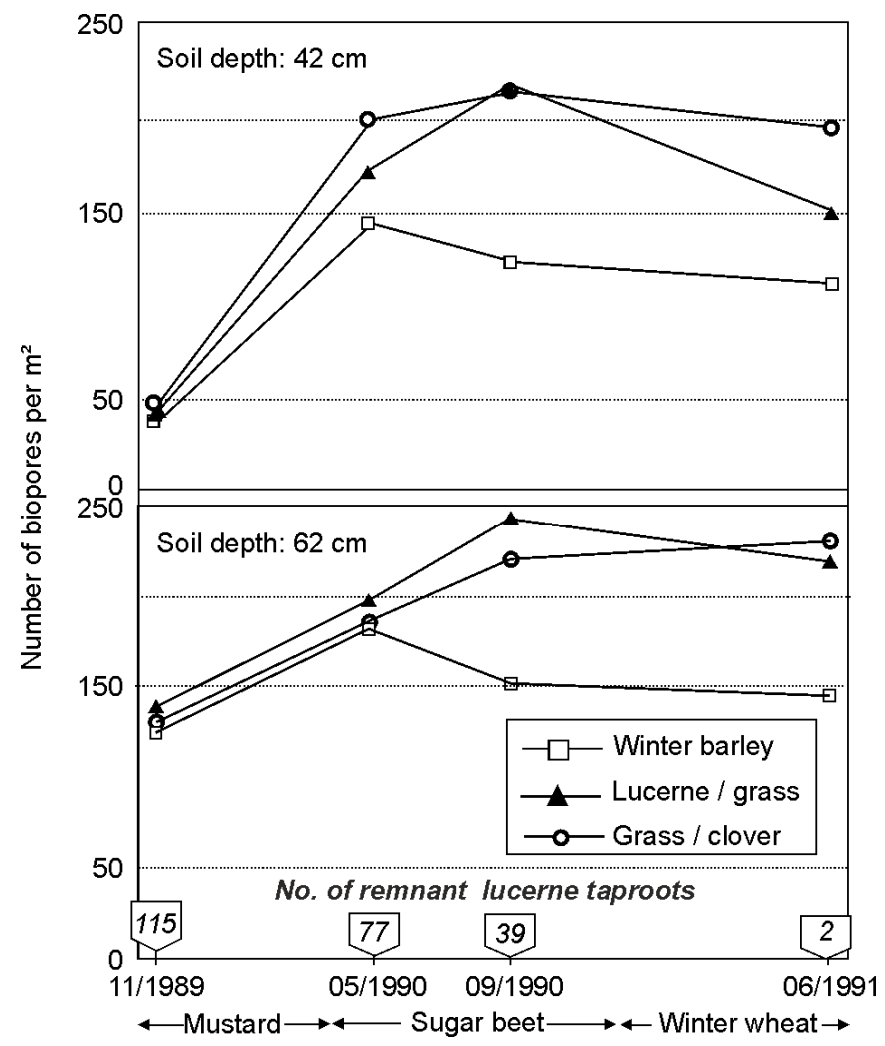

Figure 1. Density of biopores in the subsoil as a function of different precrops, soil depth and time

Source: Dreesmann (1993). Pflanzenbauliche Untersuchungen zu Rotklee-und Luzernegras-Grünbrachen in der modifizierten Fruchtfolge Zuckerrüben -Winterweizen - Wintergerste.

Figure 1 shows the effect of a modified sugar beet-winter wheat-winter barley crop rotation where winter barley was substituted by green fallows consisting of either lucerne/grass or grass/red clover. Green fallows and barley were sown in autumn 1988 and the green fallows mulched twice during the summer season of 1989. After ploughing all treatments in autumn 1989 mustard was grown as a catch crop over winter followed by sugar beet in spring 1990 (Dreesmann, 1993). Compared with the barley precrop the density of biopores at 42 and $62 \mathrm{~cm}$ soil depth was clearly higher after the grass/legume fallows. This effect lasted on the loessial soil during the following seasons of the first and second subsequent main crops, i.e. sugar beet and winter wheat. Thus, the higher number of biopores after lucerne/grass and grass/clover compared to barley precrop is attributable to the taproot systems of the legumes grown in the fallows, and secondly, as a function of residual fallow nitrogen that caused a more vigourous growth of mustard that also displays a taproot system. Thirdly, we assume a higher earthworm abundance as a function of a better feeding habitat in and after fallowing compared to barley. This hypothesis is underlined by biopore continuity which was determined by infiltrating ink through biopores. The total number of ink-marked biopores was higher even two years after the fallows, and this was largely due to the biopores greater than $5 \mathrm{~mm}$ in diameter (Figure 2) formed by earthworms. 


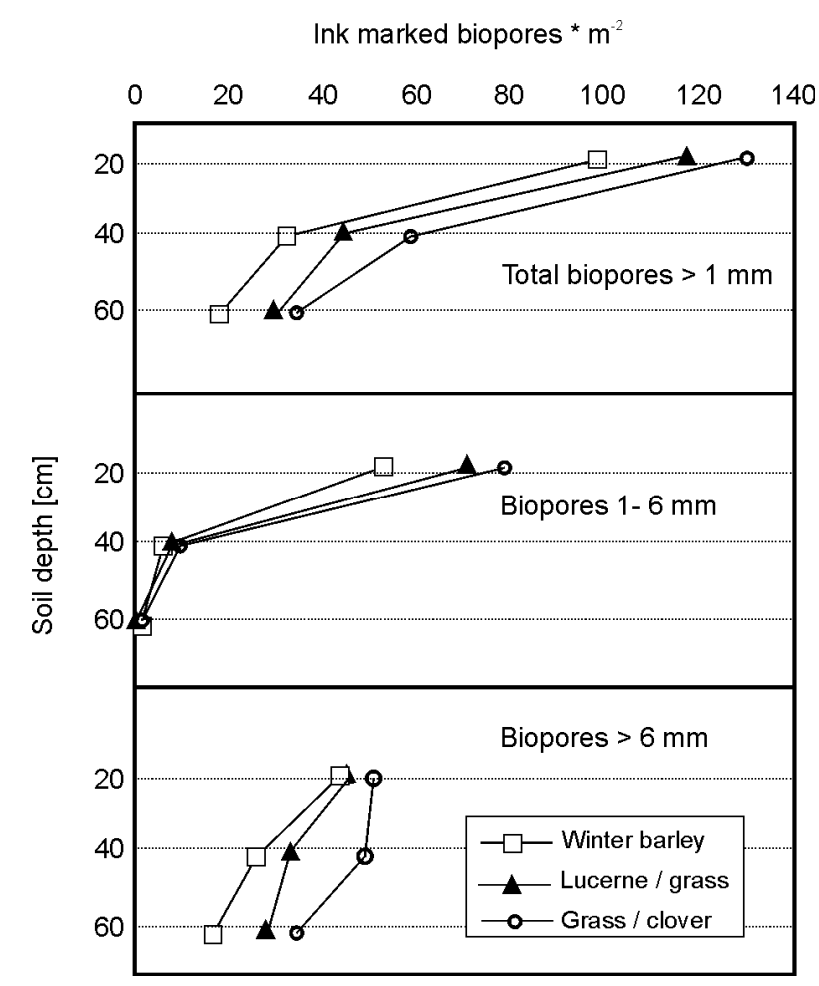

Figure 2. Continous biopores beneath second preceding crop winter wheat (see Figure 1) as a function of different precrops and soil depth

Source: Dreesmann (1993). Pflanzenbauliche Untersuchungen zu Rotklee-und Luzernegras-Grünbrachen in der modifizierten Fruchtfolge Zuckerrüben -Winterweizen - Wintergerste.

Similar results were gained with two series of field trials by the German research unit DFG 1320 that were established in 2007 and 2009. Three forage precrops with different root systems (fibrous/homorhizous roots: tall fescue, Festuca arundinacea Schreb. vs. taproots/allorhizous roots: lucerne, Medicago sativa L., chicory, Cichorium intybus L.) were grown for one, two and three years followed by subsequent non-legumes with fibrous roots and taproots (for details concerning experimental design and site see: Perkons et al. (2014) and http://www.for1320.uni-bonn.de/experimental-design/experimental-design-trialabc.pdf). All subsequent results reported in this paper refer to these field trials.

The taprooted forage crops resulted in significantly higher number of biopores in all biopore classes under study (Figure 3). Combining the extended time of soil rest with taprooting (chicory 2yrs) gave more continuous biopores compared with fibrous roots grown for one year only (fescue 1yr, Figure 4). 


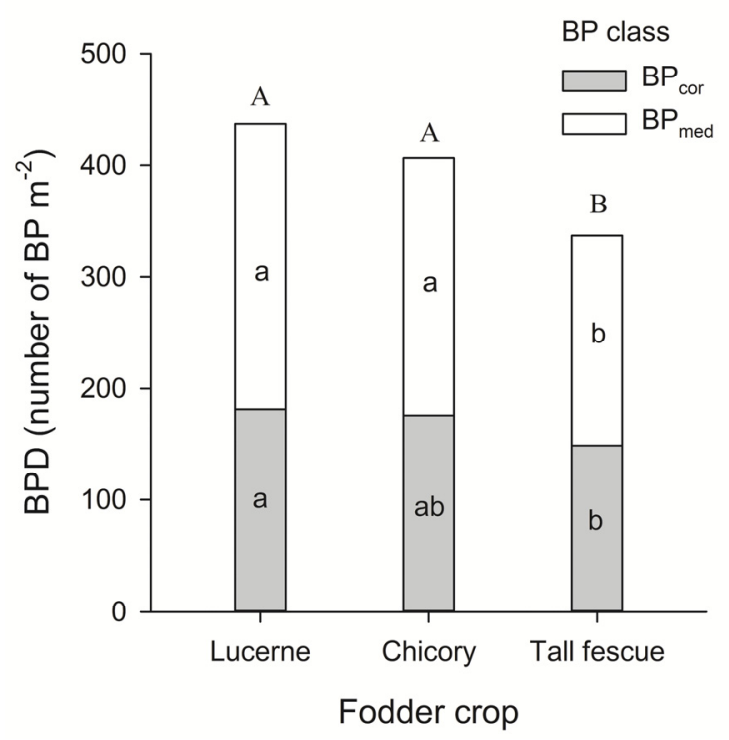

Figure 3. Biopore density after taprooted lucerne and chicory and fibrous root system of tall fescue of coarse-sized pores (BPcor: $>5 \mathrm{~mm}$ ) and medium-sized pores (BPmed: $2-5 \mathrm{~mm}$ ). Capital letters indicate significant differences between fodder crops of total BPD. Small letters indicate significant differences of crop effects within BP classes (Tukey's HSD, $\mathrm{P} \leq 0.05$ )

Source: Han et al. (submitted). Quantification of soil biopore density after perennial fodder cropping.

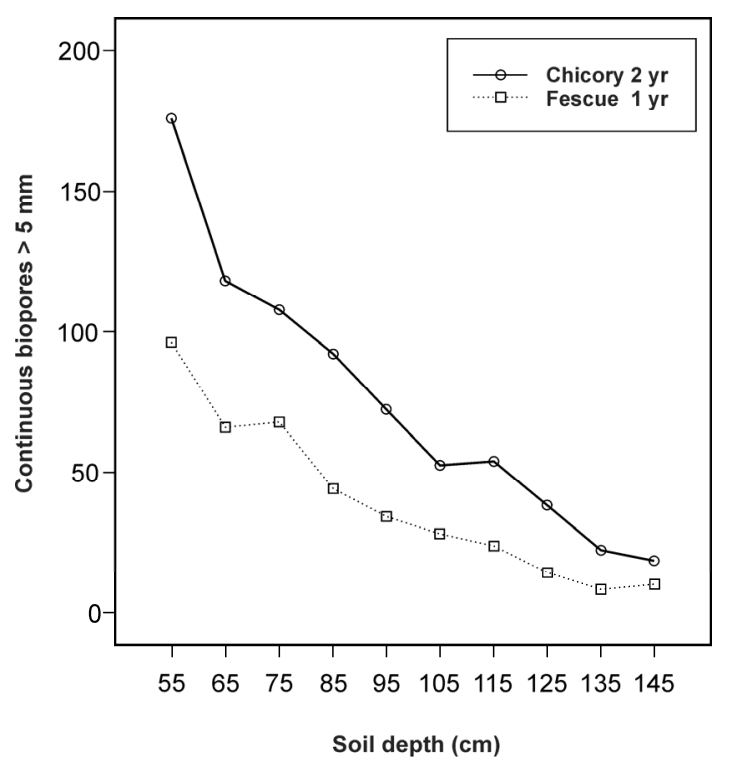

Figure 4. Continous biopores as a function of soil depth after two years chicory and one year fescue preceding crops

Source: Lütke Holz (2011). Bioporengenese durch mehrjährigen Futterbau: Einfluss von Pflanzenart und Anbaudauer auf Porengröße und -kontinuität.

\subsection{Advantages of Biopores}

During a dry spell in the 2010 season, significantly higher water extraction by the succeeding spring wheat was determined for the 90-105 cm soil depth after two years lucerne compared with two and three years of chicory and one year fescue precrop treatments (Gaiser et al., 2012). Higher biopore density after deep rooting lucerne enabled roots of spring wheat to explore the deeper soil layer more extensively. Subsoil root-length density (RLD) of winter barley grown in 2011 was significantly higher after two years chicory compared with oat-fescue 
precrops (Perkons et al., 2014).

In contrast to earlier studies that reported most of the roots in the deep subsoil growing inside large sized biopores such as earthworm burrows (e.g. Köpke, 1981; Ehlers et al., 1983), results of Perkons et al. (2014) indicated RLD of winter barley and oilseed rape in biopores comprising only about $21 \%$ of total RLD. They found taprooted crops allowing subsequent crops to establish more roots in deep soil layers, both inside and outside of large sized biopores. Increased RLD outside of large sized biopores is attributed to fine pores created by lateral roots of the taproot system or roots re-entering the bulk soil from large sized biopores.

That roots not only enter but may leave a putative soil environment given with the biopore is visualized with the photos of Figure 5 made with a videoscope. The idea of U. Köpke to use in situ endoscopy as a new method for studying root growth in biopores avoids dislocation and artifacts by introducing the endoscope 'bottom up' up to about $10 \mathrm{~cm}$ into the biopore, a method which has since been further developed (Kautz \& Köpke, 2010; Athmann et al., 2013). We consider direct endoscopic observation of root growth in its given environment an essential prerequisite for a better understanding of root-soil relationships.
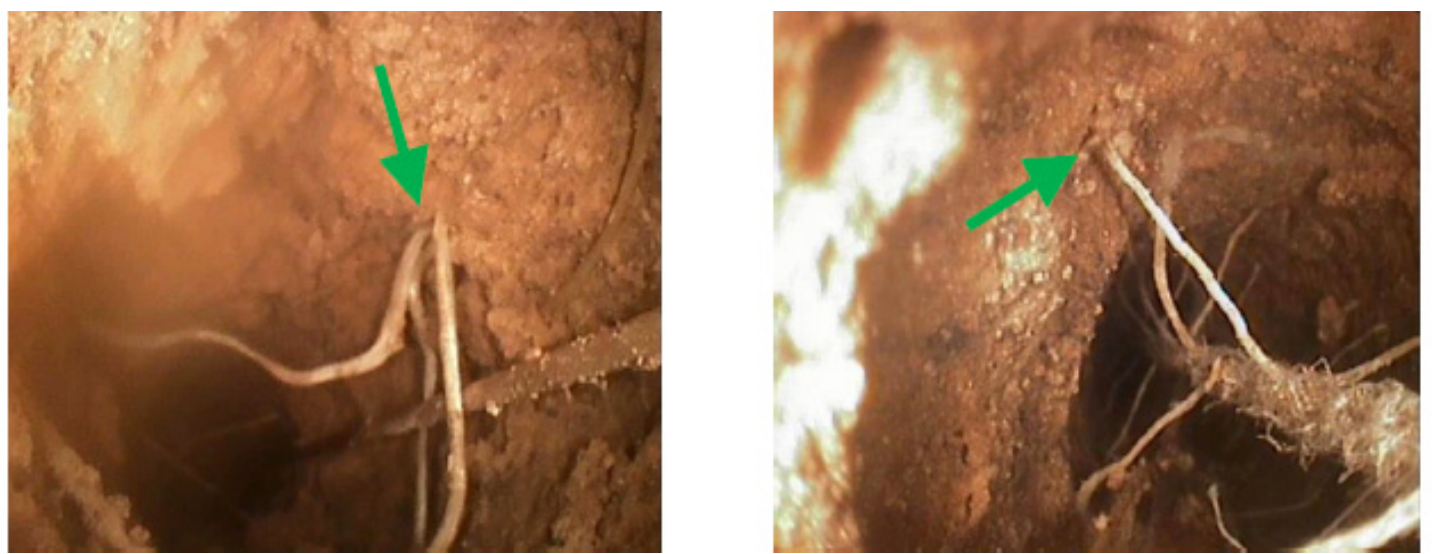

Figure 5. Root growth in biopores (pore diameters: approx. $10 \mathrm{~mm}$ ) observed by in situ endoscopy. Ingrowing roots of mallow (left); root of mallow leaving the biopore entering the bulk soil (right)

Source: Athmann et al. (2012). Einsatz angepasster Endoskopie zur Charakterisierung des Wurzelwachstums in Bioporen.

The attractiveness of biopores for root growth is not only through lesser soil impedance enabling faster vertical growth to deeper soil layers. Earthworms reallocate nutrients to deeper soil layers creating the nutrient rich pore walls by deposited wormcast, the so-called drilosphere. When compared with the bulk soil most crop growth improving soil chemical and soil microbial parameters of the drilosphere are higher (Kautz et al., 2013a). After taprooted lucerne and chicory crops the $\mathrm{P}_{\mathrm{CAL}}$ concentration in linings of biopores larger than $2 \mathrm{~mm}$ was up to 5 fold higher than the $\mathrm{P}_{\mathrm{CAL}}$ concentration in the bulk soil and higher than after fescue (Barej et al., 2014).

Figure 6 shows higher soil $\mathrm{N}$ and $\mathrm{C}$ concentrations in biopores with earthworms when compared with the bulk soil concentrations. Root lengths of winter barley in individual biopores show that elevated $\mathrm{N}$ concentrations in pore walls can facilitate the exploration of the subsoil by crop roots (Figure 7). Thus, the effect of earthworm burrows goes beyond bioporing by taproots only. 


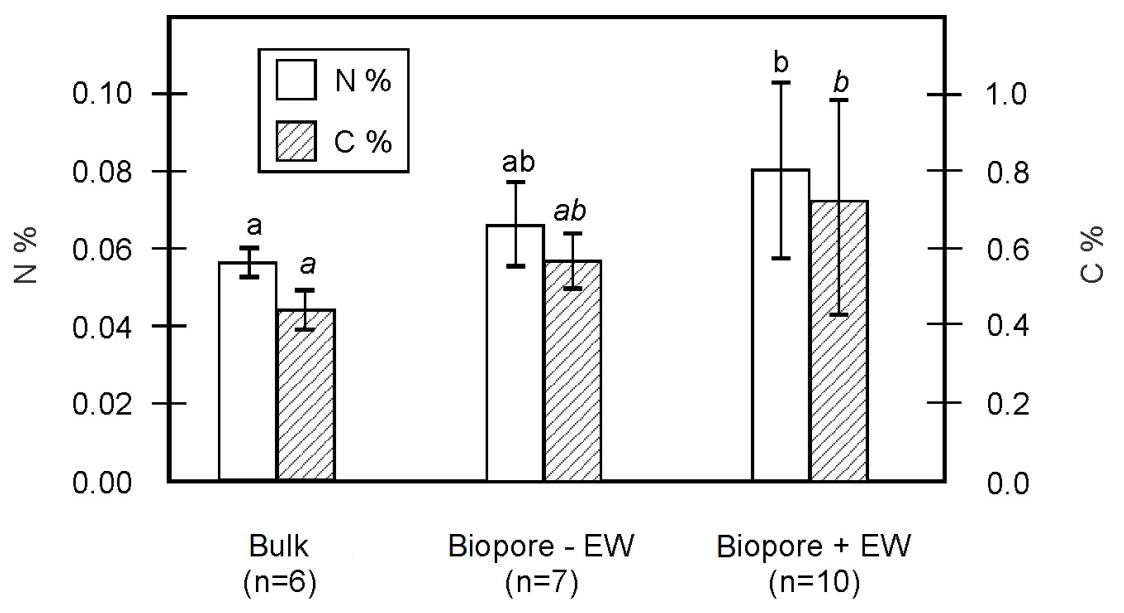

Figure 6. $\mathrm{N}$ concentrations and $\mathrm{C}$ concentrations in bulk soil and biopores without earthworms (-EW) and with earthworms (+EW) according to endoscopy images

Source: Athmann et al. (2014). Biopore characterization with in situ endoscopy: Influence of earthworms on carbon and nitrogen contents.

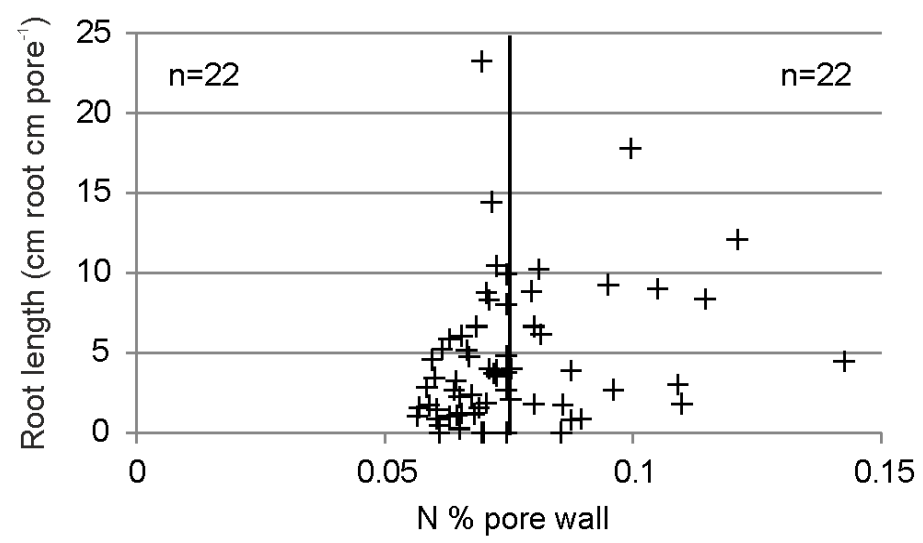

Figure 7. Root length of winter barley as affected by $\mathrm{N}$ concentrations of individual pore walls

Source: Kautz et al. (2014b). Growth of barley (Hordeum vulgare L.) roots in biopores with different carbon and nitrogen contents.

Since after all fodder crops high amounts of shoot mass were left as mulch on the soil surface, earthworm biomass and abundance were not affected by fodder crop species but significantly increased by cropping duration. On the other hand the duration of soil rest under taprooted fodder crops should not only result in higher abundance and biomass of earthworms (Figure 8) but also in the advantage of bigger sized pores and higher amounts of re-allocated nutrients as a function of the increased share of active adults. Actually, the proportion of adult individuals of Lumbricus terrestris re-colonizing existing biopores or creating new pores, thus increasing the drilosphere space was significantly higher compared with sub-adults (Kautz et al., 2014a). 

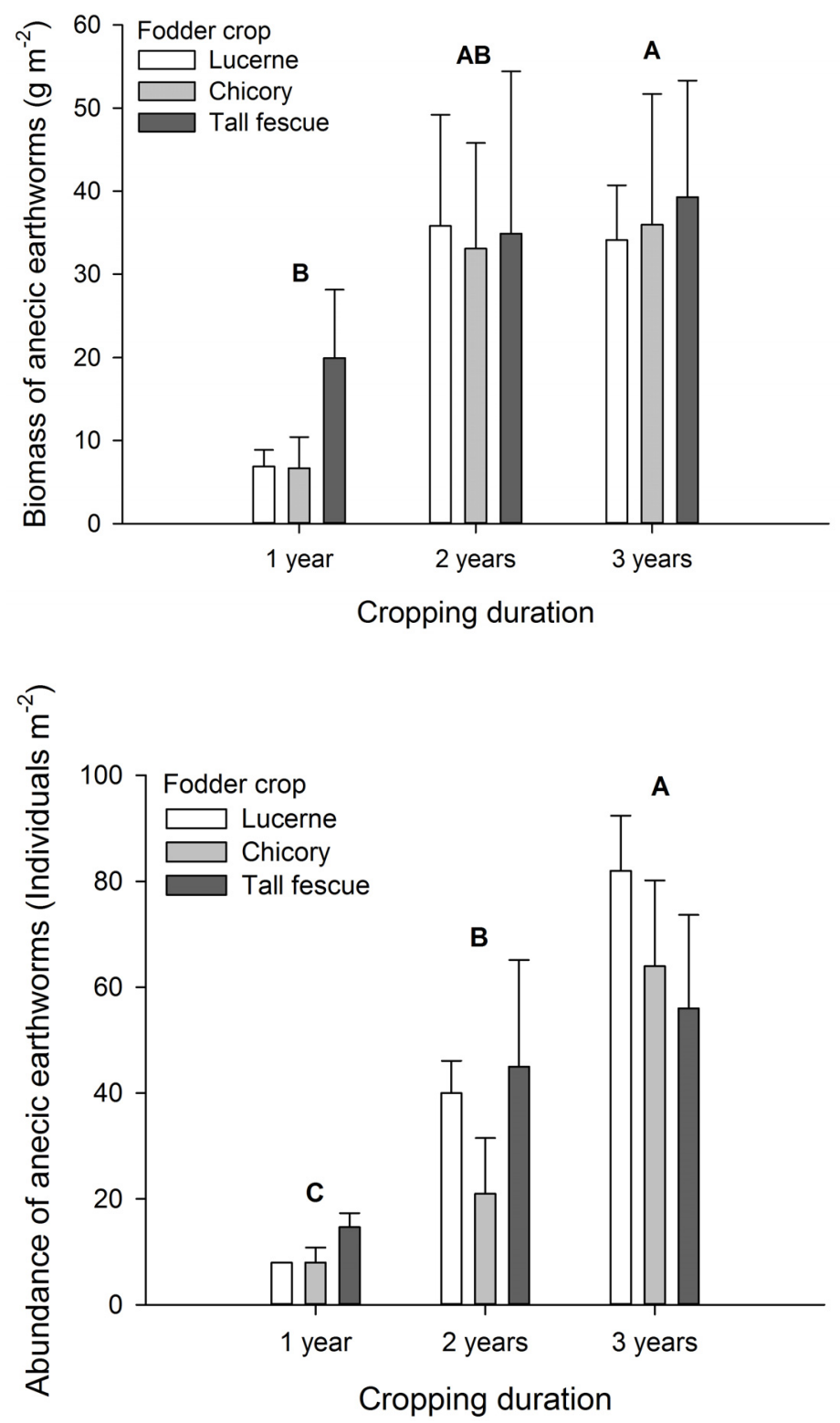

Figure 8. Earthworm biomass and abundance as affected by precrop fodder crops and cropping duration. Letters indicate significant differences affected by cropping duration (Tukey's HSD, $\mathrm{P} \leq 0.05$ )

Source: Han et al. (submitted). Quantification of soil biopore density after perennial fodder cropping.

\section{Practical Application-Biopore Management}

Since fodder cropping is essential in mixed farms with ruminants, this farm type is able to use taprooted fodder cropping better than arable farms. Nevertheless, new approaches exist in arable and vegetable farms to use fodder legumes as donor crops for N. In so-called 'cut and carry systems' farmers apply the shoot material of the fodder legumes not necessarily included to the crop rotation to high N-demanding and high value crops (Figure 9). Since biopores in the subsoil can persist over years, the strategy 'cut and create' hypothesizes the progression of biopore density as a function of cycling perennial taproot fodder cropping and the use of the mouldboard plough. We assume that cutting the biopores via ploughing ('cut and create') will further increase the number of new taproot created biopores during the next repeated growing cycle since new taproots may not necessarily find and use older biopores from the former taproot cycle. 


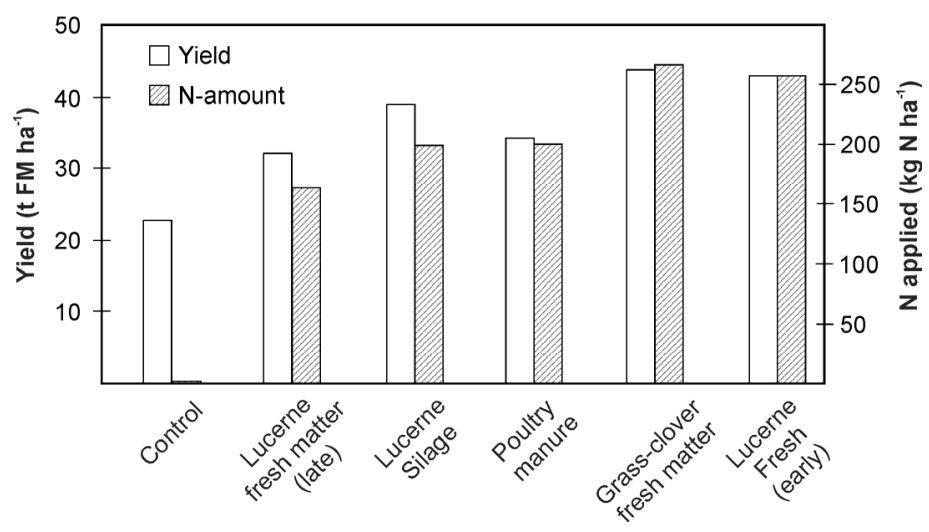

Figure 9. Spinach yield as affected by nitrogen sources of different origin

Source: Burgt et al. (2011, altered and amended). Developing novel farming systems: effective use of nutrients from cover crops in intensive Organic Farming.

In the EU Basic Payment Scheme starting in 2015, farmers have to comply with greening requirements. The aim of Ecological Focus Areas (EFA) is to safeguard and improve biodiversity on farms on at least 5\% of set-aside area per farm. Especially in regions dominated by arable farms it is doubtful whether farmers would establish measures like hedgerows and broader sized field margins. But farmers might be interested to use our above outlined strategies on headlands. These parts of arable fields are often poorly structured and compacted, thus resulting in less productivity with lower gross margins compared with within-field soil conditions and resulting productivity. On headland sites of organically managed commercial farms, perennial grass-clover and alfalfa resulted in a higher density of larger sized biopores (Kautz et al., 2010). Thus, the strategy of 'greening the headlands' with perennial taprooted fodder legumes as a cost-efficient and attractive strategy was previously suggested (Köpke \& Wiggering, 2013). Besides improving the soil structure, cropping of taprooted flowering fodder crops that are left uncut over winter is considered able to additionally enhance biodiversity - at least of insects, field birds and smaller mammals - via providing feeding and hibernation habitats.

\section{Conclusions and Outlook}

Extended biopore systems and the properties of the drilosphere are a function of crop specific root systems and earthworm activity. Crop rotation design should include taproot systems of perennials for accessing deeper soil layers in order to make nutrients available from the solid phase and to create biopores. When a soil rest phase and high-quality crop residues are provided, the earthworm population will further increase biopore density and enhance the nutrient status and physical stability of the drilosphere. Pore walls enriched in nutrients re-allocated by earthworms can promote nutrient acquisition from the subsoil. Cutting biopores by tillage and repeating the strategy may lead to increased biopore density and soil quality ('cut and create'). Mixed farming systems enable efficient implementation of taprooted fodder crops. Stockless farms can use 'cut and carry' systems with the same effects of soil improvement. Drought or scarcity of nutrients in the topsoil should increase the share of nutrients taken from the subsoil in total crop uptake. Thus, effects of climate change may better be balanced via these strategies of subsoil structure heterogenization. On headlands soil structure can be improved and above ground environmental services generated ('greening', Ecological Focus Area). The effects of enhanced access of crop roots to deeper soil layers and their lasting biopores have been proved for non-swelling loess derived soils and may not hold true for other soils especially coarse sandy soil.

\section{Acknowledgements}

Funding of the project (Research unit FOR1320, coordinator U. Köpke) by the German Research Foundation (DFG) and supporting the oral presentation of the conference paper by OECD, USDA-NIFA and ICROFS is gratefully acknowledged. We would like to thank the following people for thouroughly conducting the field experiments, their contribution and cooperation: Ning Huang, Paul Martin Küpper, Marcel Lüsebrink, Ute Perkons, Henning Riebeling, Johannes Siebigteroth, Frank Täufer, Christian Dahn, Katharina Lütke Holz and Christoph Stumm. 


\section{References}

Athmann, M., Kautz, T., \& Köpke, U. (2012). Einsatz angepasster Endoskopie zur Charakterisierung des Wurzelwachstums in Bioporen. In W. Merbach, S. Ruppel \& J. Augustin (Eds.), Mitteilungen Agrarwissenschaften Bd. 20, 22. Borkheider Seminar zur Ökophysiologie des Wurzelraums (pp. 13-19). Verlag Dr. Köster, Berlin.

Athmann, M., Kautz, T., Pude, R., \& Köpke, U. (2013). Root growth in biopores - evaluation with in situ endoscopy. Plant Soil, 371(1), 179-190. http://dx.doi.org/10.1007/s11104-013-1673-5

Athmann, M., Huang, N., Kautz, T., \& Köpke, U. (2014). Biopore characterization with in situ endoscopy: Influence of earthworms on carbon and nitrogen contents. In G. Rahmann \& U. Aksoy (Eds.), Building Organic Bridges, Johann Heinrich von Thünen-Institut, Braunschweig, Germany, 2, Thuenen Report, Nr. 20, pp. 391-394.

Barej, J. A. M., Pätzold, S., Perkons, U., \& Amelung, W. (2014). Phosphorus fractions in bulk subsoil and its biopore systems: European Journal of Soil Science, 65, 553-561. http://dx.doi.org/10.1111/ejss.12124

Burgt, G. J. H. M. van der, Scholberg, J., \& Koopmans, C. J. (2011). Developing novel farming systems: effective use of nutrients from cover crops in intensive Organic Farming. In D. Neuhoff, Sang Mok Sohn, Ssekyewa, C., Halberg, N., I. A. Rasmussen, \& J. Hermansen (Eds.), Organic is Life - Knowledge for Tomorrow. Volume 1 - Organic Crop Production. Proc. Third Sci Conf International Society of Organic Agriculture Research (ISOFAR), Namyangju, Korea, 28 Sep - 01 Oct 2011, 32-35.

Dreesmann, S. (1993). Pflanzenbauliche Untersuchungen zu Rotklee- und Luzernegras-Grünbrachen in der modifizierten Fruchtfolge Zuckerrüben -Winterweizen -Wintergerste. Dissertation. Bonn University, p. 116.

Ehlers, W., Köpke, U., Hesse, F., \& Böhm, W. (1983). Penetration resistance and root growth of oats in tilled and untilled loess soil. Soil and Tillage Research, 3, 261-275. http://dx.doi.org/10.1016/0167-1987(83)90027-2

Gaiser, T., Perkons, U., Küpper, P. M., Puschmann, D. U., Peth, S., Kautz, T., ...Köpke, U. (2012). Evidence of improved water uptake from subsoil by spring wheat following lucerne in a temperate humid climate. Field Crops Research, 126, 56-62. http://dx.doi.org/10.1016/j.fcr.2011.09.019

Godlinski, F., Leinweber, P., Meissner, R., \& Seeger J. (2004). Phosphorus status of soil and leaching losses: results from operating and dismantled lysimeters after 15 experimental years. Nutrient Cycling in Agroecosystems, 68(1), 47-57. http://dx.doi.org/10.1023/B:FRES.0000012235.80656.cd

Han, E., Kautz, T., Perkons, U., Lüsebrink, M., \& Köpke, U. (submitted). Quantification of soil biopore density after perennial fodder cropping. Plant Soil.

Howard, A. (1943). An Agricultural Testament. Oxford: Oxford University Press.

Kautz, T. (2014). Research on subsoil biopores and their functions in organically managed soils: A review. Renewable Agriculture and Food Systems. http://dx.doi.org/10.1017/S1742170513000549

Kautz, T., \& Köpke, U. (2010). In situ endoscopy: New insights to root growth in biopores. Plant Biosystems 144, 440-442. http://dx.doi.org/10.1080/11263501003726185

Kautz, T., Stumm, C., Kösters, R., \& Köpke, U. (2010). Effects of perennial fodder crops on soil structure in agricultural headlands. Journal of Plant Nutrition and Soil Science, 173, 490-501. http://dx.doi.org/10.1002/jpln.200900216

Kautz, T., Amelung, W., Ewert, F., Gaiser, T., Horn, R., Jahn, R., ... Köpke, U. (2013a). Nutrient acquisition from arable subsoils in temperate climates: A review. Soil Biology and Biochemistry, 57, 1003-1022. http://dx.doi.org/10.1016/j.soilbio.2012.09.014

Kautz, T., Perkons, U., Athmann, M., Pude, R., \& Köpke, U. (2013b). Barley roots are not constrained to large-sized biopores in the subsoil of a deep Haplic Luvisol. Biology and Fertility of Soils, 49, 959-963. http://dx.doi.org/10.1007/s00374-013-0783-9

Kautz, T., Lüsebrink, M., Pätzold, S. Vetterlein, D., Pude, R., Athmann, M., ... Köpke, U. (2014a). Contribution of anecic earthworms to biopore formation during cultivation of perennial ley crops. Pedobiologia, 57, 47-52. http://dx.doi.org/10.1016/j.pedobi.2013.09.008

Kautz, T., Athmann, M., \& Köpke, U. (2014b). Growth of barley (Hordeum vulgare L.) roots in biopores with differing carbon and nitrogen contents. In G. Rahmann \& U. Aksoy, (Eds.), Building Organic Bridges, 
Johann Heinrich von Thünen-Institut, Braunschweig, Germany, 2, Thuenen Report, Nr. 20, 391-394.

Köpke, U. (1981). A comparison of methods for measuring root growth of field crops [oats, Avena sativa L.]. Zeitschrift fuer Acker und Pflanzenbau, 150, 39-49.

Köpke, U. (1995). Nutrient management in organic farming systems. The case of nitrogen. Biological Agriculture and Horticulture, 11(1-2), 15-29. http://dx.doi.org/10.1080/01448765.1995.9754690

Köpke, U., \& Wiggering, H. (2013). Vorgewende als Vorrangfläche! DLG-Mitteilungen, 4, 86-88.

Lütke Holz, K. E. (2011). Bioporengenese durch mehrjährigen Futterbau: Einfluss von Pflanzenart und Anbaudauer auf Porengröße und -kontinuität. Bachelor thesis, Institute of Organic Agriculture, University of Bonn.

Perkons, U., Kautz, T., Uteau, D., Peth, S., Geier, V., Thomas, K., ... Köpke, U. (2014). Root-length densities of various annual crops following crops with contrasting root systems. Soil and Tillage Research, 137, 50-57. http://dx.doi.org/10.1016/j.still.2013.11.005

Schulz-Lupitz, A. (1895). Zwischenfruchtbau auf leichtem Boden. Berlin.

\section{Copyrights}

Copyright for this article is retained by the author(s), with first publication rights granted to the journal.

This is an open-access article distributed under the terms and conditions of the Creative Commons Attribution license (http://creativecommons.org/licenses/by/3.0/). 